UDC339.137.2

DOI: 10.18524/2303-9914.2021.1(38).234686

L.V. Tranchenko ${ }^{1}$, DrSc (Economic), Prof.

V.V. Yavorska ${ }^{2}$, DrSc (Geography), Prof.

V.A. Sych ${ }^{2}$, PhD (Geography), Docent

S.V. Timchuk ${ }^{1}$, PhD (Economic), Docent

N.V. Tereschuk ${ }^{1}, \mathrm{PhD}$ (Economic), Docent

${ }^{1}$ Uman National University of Horticulture,

Department of Tourism and Hotel and Restaurant Business,

Institute st., 1, Uman, Cherkasy region, 20305, Ukraine

${ }^{2}$ Odesa I. I. Mechnikov National University,

Department of Economic and Social Geography and Tourism,

Dvorianska St., 2, Odessa, 65082, Ukraine

yavorskaya@onu.edu.ua

\title{
FEATURES OF COMMUNICATION IN THE HOSPITALITY INDUSTRY IN THE CONTEXT OF GLOBALIZATION
}

In this study, the authors raise the question that tourism, the tourism industry constructs a special space created by hotels, transport infrastructure, a special form of organization of tourist facilities, and so on. The beginning of the XXI century is characterized by the dominance of globalization trends in the development of international relations. The world market of goods and services is becoming a single global economic space in which the development of a particular segment is a natural consequence of the effectiveness of internationalization, transnationalization and international communication. The purpose of the article is to find out the communication features in the field of tourism in the context of globalization of modern society. The task of the research is to determine the ways for the tourist to overcome the inconveniences when getting acquainted with the foreign culture of other countries; to investigate the optimal model of interaction between national and international parameters of service culture in the field of hospitality. In terms of cross-cultural communications, characteristic of tourism as one of the dominant factors in the globalization of modern society and the front of the clash of cultures, it is necessary to take into account national characteristics, manifested in latent form in relation to the world and values, behaviour, communication methods, inclinations and passions, in a way of life, in traditions and habits. A safe form of immersion in a foreign environment is a culture of service, and European standards act as a mediating space between tourists and foreign culture. The standardized culture of service and the accepted business etiquette are capable to compensate a culture shock, for this purpose in the country professional culture of the employee of sphere of hospitality has to develop.

Key words: tourism, tourism industry, intercultural communications, social space of tourism, hospitality. 


\section{INTRODUCTION}

An expanded understanding of tourism allows us to identify not only the methodological basis for its sociological analysis, but also to identify the main stages and levels of decomposition, the composition of elements, actors, dominant factors and aggregated requirements for social infrastructure of tourism. The expansion of the subject area of tourism research and the inclusion of a wide range of social relations and interactions allows us to distinguish the sphere of tourism in an independent dynamic object of society, characterized by a concentration of different types and forms of social relations, based on tourism goals and values. The content of tourism as a social phenomenon allows us to consider tourism as a multifaceted process, which is manifested in all spheres of public life. The specificity of the content contributes to the uniqueness of the integration of tourism into the structure of certain relations, and this is reflected in the system of stereotypes - patterns of behaviour and relationships in the field of tourism. Throughout his life, each person, living certain periods, is an actor who improves his skills in a wide "theatre" of social relations (Coen, 1984).

We are interested in a social person, his behaviour in different life situations, in relationships with different people and groups. This question is facing historians, philosophers, psychologists and sociologists. One of the types of role-playing human behaviour is status and "etiquette" relationships. The more realistically the role of a cultured person is played, the more this person's stay will correspond to society and a certain social group. Beginning of the XXI century is characterized by the domination of globalization trends in the process of developing international relations (Globalization and the Third World, 2006). The tourism market turns into a single global economic space, in which the development of a separate segment becomes a natural consequence of the efficiency of processes of internationalization, transnationalization and international communication. Issues of theoretical and methodological nature, the conceptual apparatus of tourism and hospitality are reflected in the works of O. Lyubitseva, M. Malska, F. Kotler, K. Dinny, S. Briggs. A large number of scientific researches of domestic and foreign scientists are devoted to the study of the problem of intercultural communication, among which E. Koc. Chorna, M. Lukashevich, D. Gelrigel, I. Zorin, G. Marcel, S. Yavonenko and others. Tourism is traditionally seen as a branch of the economy, or as a socio-cultural phenomenon. In a globalized society, tourism needs to be studied from the standpoint of a specific social phenomenon; the principles of social interaction in tourism today should be distinguished. The purpose of the article is to find out the communication features in the field of tourism in the context of globalization of modern society. The task of the research is to determine the ways for the tourist to overcome the inconveniences when getting acquainted with the foreign culture of other countries; to investigate the optimal model of interaction between national and international parameters of service culture in the field of services. 


\section{DATA AND METHODS}

The article uses philosophical methods to explain the contradictions and complex development of such concepts as intercultural interactions, the social space of the tourist; the dialectical method was used to consider the complexities of intercultural interaction of tourists in a foreign environment in relation to the skills and competencies of service professionals; the method of modeling was used to simplify the behavior of tourists, the formation of the social space of tourism in contact with another culture.

\section{RESEARCH RESULTS AND DISCUSSION}

The above aspects of the analysis of the subject area of research in tourism are complicated by the need to take into account national characteristics, which are manifested in a latent form in relation to the world and value system, behaviour, communication methods, inclinations and passions, lifestyle, traditions and habits. These studies are especially important in the context of cross-cultural communications, characteristic of tourism as one of the dominant factors in the globalization of modern society and the front of the clash of cultures (Chhabra, Healy \& Sills, 2003). According to the existing concepts of clash of cultures, there are two main approaches: according to the first, it is argued that in the modern world there is a "blurring" of national borders, the formation of common life values, norms and rules in the globalization of modern society (for example, a student educated in another country perceives and accepts the peculiarities of national thinking and behaviour of the people of the country where he studied); the second point of view, on the contrary, gives national features a central place in interethnic communication, believing that "communication difficulties arise due to differences in expectations."

Supporters from this point of view note that at the stage of the origin of cooperation national differences are not noticed, but it is necessary to have a conflict situation, so they begin to acquire a dominant role. The constant companion of the clash of cultures is culture shock - the unconscious reaction of a person in contact with another's culture, the state of psychological confusion and spiritual disorientation experienced by a person without special training, who found himself in a socio-cultural environment alien to him (Oberg, 1960). This conceptual apparatus is widely used in ethnic psychology, social anthropology, in recreation. Gradually it finds its place in sociology. Signs of culture shock are well studied on the example of migrants, the vast majority of whom somehow experience the stress of encountering a new cultural practice. Cultural shock is especially acute in a situation where space is not perceived as "foreign".

A foreign tourist trip, as a rule, is not accompanied by a deep shock of a person from his encounter with the culture of other nations. However, some signs of culture shock may occur, especially in those who are on vacation for the first time in a completely unfamiliar country. Despite the fact that the tourist, in contrast to the migrant, 
especially a temporary migrant, consciously enters the space of another culture, the shock is possible (Koc, 2020). This is the difference between a glossy booklet and a very real dust, and the inconvenience of the room, and not very pleasant smells in the restaurant, and unusual patterns of human behavior, and the mode of operation of shops, and much more. Such a reaction of a tourist can be minimized if he is prepared for a meeting with another socio-cultural reality, pre-informed about the basic norms of behavior in public places, warned about facts, events and more. Similar reactions to culture shock can be experienced by local people in cases where their territory suddenly becomes a place of pilgrimage for tourists, which requires special efforts from tourism organizers to neutralize the residents of this syndrome.

Today, every tourist going abroad should ask such questions and carefully prepare for the trip. Any tourist, going abroad, feels the collision of several cultures: the culture of the country from which the tourist came; the culture of the country where the tourist is resting; service culture; tourist recreation culture. The interaction of cultures can be represented in the form of such a model (Fig. 1).

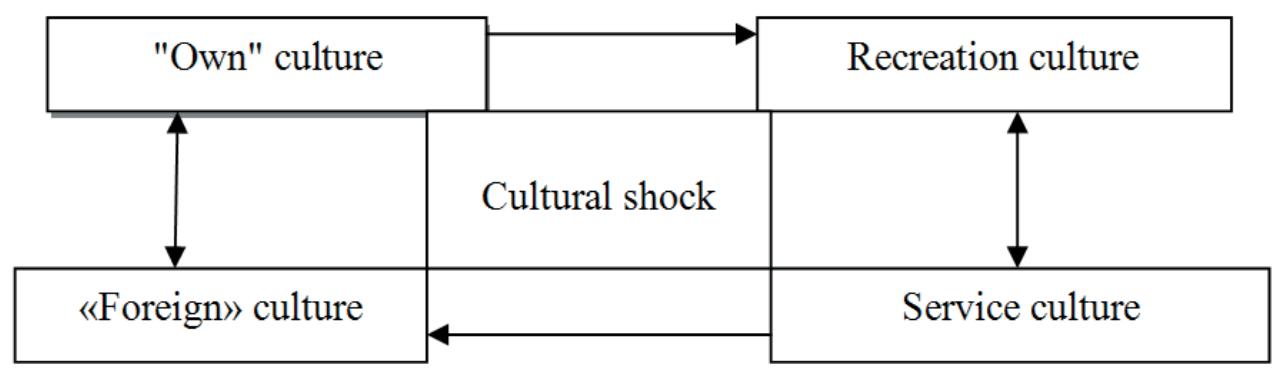

Fig. 1. Interaction of cultures

The culture of the country from which the tourist came - is a system of values, beliefs, a set of moral stereotypes, behaviors, experiences and knowledge, which are assigned to the social agent. Here are formed the basic background practices, reproduced by man in addition to reflection. It is they who create the layer of social patterns that are prominent and fixed levels and distinguish the representative of one culture from the representative of another, one society from another. It is also important that one's own stereotypes are not understood, but perceived as the only possible ones. That is why the stereotypes of another life and another community are so painfully perceived (Gusfield, 1984).

The culture of the country where the tourist visits is a "foreign" culture. This concept is identical with the sign "minus" the concept of "culture of their country", given that the values and beliefs, behaviors and lifestyles, traditions of different countries and peoples differ from each other. Here we can distinguish two levels of social conceptualization of the concept of "Foreign Culture". The first level is fixed in advertising and information booklets, reflected on tourist sites. This level of 
alienation does not cause culture shock. On the contrary, it is its presence that defines the space that we have designated by the term "Social space of tourism". More precisely, it is one of its important elements. This term include ethnographic features, local holidays, cultural and artistic monuments, etc. without this "Foreign Culture" tourism would not be very meaningful and not particularly motivated. Even when it comes about domestic tourism, it is usually directed towards some object, marked as "other": from land to the sea, from the plains - to the mountains, etc. Another variant of "foreignness" has less to do with tourism, but more to do with sociology. Unfamiliar social space is endowed with other people's meanings, described by other mechanisms. Due to this, in this social space, which includes tourists, there is a different distribution of approved or disapproved practices.

In the extreme case, the practices themselves are different. This is especially noticeable when traveling to a country with a different denomination, belonging to a different socio-cultural area. Here, ordinary communication can cause serious conflict (Moufakkir, 2013). And, importantly, it is not always possible to predict what exactly can cause a conflict situation. For example, somewhere in the market it is accepted to bargain, and somewhere it is perceived extremely negatively. The gender stereotypes, food traditions, addressing passers-by, greetings and much more are different and in different countries.

Modern travel agencies seek to protect its customers. A great deal is carried out, which is largely based on experience and sociological studies. An analysis of typical situations where conflict and simply inconvenience for guests is possible is performed. Sightseeing and specialized information resources are being developed for those who want to visit this place or this country. But to completely protect the tourist from the unwanted state of affairs with a direct collision with a «foreign» social reality is quite difficult. Particularly acute this problem is in recent years, when the geography of tourism has extremely expanded. Today many countries which were recently not available for tourism gain popularity: countries of Central Africa and Central Asia, exotic countries of Southeast Asia, etc. Unfortunately, the culture of these countries, and the level of medical provision is often insufficient to ensure that it is not something comfort, but also simply security (Otto \& Ritchie, 1996).

Many actions are completely neutral in the European area can cause police persecution. A much more reliable way to protect is the building of a particular intermediary structure. This structure is not absolutely unfamiliar. More precisely, it is alien, and includes a necessary set of ethnographic features (that is, someone else's social space of the first type), and in force it completely replaces on the tourist immersion in a foreign medium. More precisely, there is a safe form of immersion. At the same time, such space cuts off all the dangerous forms of social interaction.

So space serves "culture of service". Culture of service is a degree of excellence (level of development) of the population service in psychological, aesthetic, ethical, organizational and technological aspects. It is here the ethics of the tourist industry is recorded; the communicative features that provide tourists with the 
maximum possible level of comfort are forming. In the above scheme, this type of communication we marked the concept of "tourist holiday culture". Culture of tourist recreation is holding a person free time by recreational activity in accordance with their tastes, preferences. The culture of another country begins for a foreigner with unusual food, incomprehensible facial expressions and behavior (Westcott \& Anderson, 2020). Most tourists are limited to minimal acquaintance with the country where it is going to spend a vacation, but often such information introduces people to deceive, that are, it is difficult to evaluate objectively. Significant assistance in overcoming such states provides a solid relationship with its own culture. People who identify themselves with their own culture, easier to transfer collisions with a country's crop culture. One who is self-sufficient can abstract from their own "I am", avoid awkward provisions; survive the difficulties of perceiving another culture. Another way to overcome the negative consequences in collision of cultures is that all over the world is a hotel business based on European standards (Michaelides, 2017).

Tourists can afford to visit foreign countries, without finding themselves in the authorities of unfamiliar customs. Actually "European standards" and are the same, an intermediary space. Knowledge of these standards allows hotel staff and tourists themselves build a peculiar security wall around the tourist space. We can say that the European culture of hotels serving is a filter of perception of someone else's culture, as a result of this - the absence of experiences, negative emotions and stressful state. But a similar "filter" in the hotel prevents the perception of life of other peoples, their cultural achievements, all that reproduces a unique atmosphere of a tourist city.

There are several paths to overcome this problem. The first is characteristic for countries with a relatively high standard of life, a stable economic and political situation. Here the hotel marks the limited tourist social space than it provides it. At the same time, tourist areas of the city are equipped with a certain infrastructure, are marked as tourist places. Otherwise, there is a situation in countries with a relatively low living standard and essential, compared to the European tradition, differences in the set of practices. Here the hotel becomes the main place of tourist stay, its space. As a rule, the hotel here becomes an autonomous space with its own beaches, restaurants, entertainment centers, its own medicine base, etc.

Departure beyond the hotel is most often carried out as a departure to someone else's space. It involves special means of moving, professional accompanying, etc. Of course, nobody will ban the tourist to make an exit to the city on its own. However, they are clearly aware that it leaves a safe zone, taking risks and responsibility. In addition, European culture of service is an effective means of overcoming cultural shock in the event that all hotel clients are representatives of one culture, one country. For efficient using of tourist resources for taking tourists, especially foreign tourists, it is necessary to carefully study their lifestyle, characteristics of a national character, the level of training and the possibility of adequate perception of tourist 
interest objects. All these indicators and characteristics are taken into account when designing a tourist product (Hospitality industry, 2019).

The method of compensating for a cultural shock is a standardized culture of service and is adopted in society business etiquette. The aggregate of these competencies researchers have marked by the term - the culture of service. The culture of service belongs to the national sphere of services of a separate country, to separate industries, to each organization and to each group. However, the culture of service forms the same standards of service. There is a need to develop an optimal model of interaction between national and international parameters of the service culture (Tourism and Culture Synergies, 2018).

In Ukraine, the principles of interaction of the seller and the buyer, artisan and client, which make up a certain basis of national communication, have long been developed. At the same time, the process of globalization has led to the development of general parameters of interaction in the service sector. Without their reproduction it is impossible successful functioning in this market. Before the modern Ukrainian service there is a task of combining national features and international principles of service culture. In any country, service workers and maintenance are used by national traditions of service, if they do not contradict modern requirements. The special classes are carried out with employees also are disassembled errors in service. The employee of the contact zone is important to possess the ability to communicate with the client, the ability to unobtrusively identify its needs and advantages, in a timely manner to offer the necessary service.

The service personnel must remain benevolent and polite throughout the contact with the client. Even if he is not solved on the purchase of a service, you can not irrigate, especially expressing dissatisfaction. And if the client did not decide on the acquisition of a service, employees must take it as a potential buyer, inviting the client to go to them once again.

Professional culture of employees is a system of qualities that provides a level of labor, professional activity and determines the attitude of an employee to work (Kuslovan, 2003). The general culture of the employee consists of the unity of conviction in the social significance of labor and his profession, readiness to effectively and qualitatively solves emerging production tasks, a set of knowledge of theory and practice of management, the possibility of expanding professional skills. The content of professional ethics is being codes of behavior that orders a certain type of moral relationships within the framework of professional activity and ways to justify of these codes. The hotel staff is constantly in the process of communicating with customers, with each other, managers, representatives of various organizations (partners, competitors, etc.). Consequently, the staff must have communicative skills. In the service sector, the importance of ethical norms is felt not only in the interaction of employees with consumers, but also employees among themselves.

Many moral principles and ethical standards, mentioned above, the employee must be observed in relations with colleagues. At the enterprise of the service sphere 
special importance acquires a moral climate, where there are no conflicts, there are no humiliated, irritated, indifferent, all employee relate to each other with respect and attention. It is exclusively important to create a mutual assistance atmosphere in the collectivity, the ability to work in a team (Baum, 2002). Intelligence, naturalness, sense of measure, benevolence, politeness and tactfulness in relation to people are those qualities that will help in any life situations, especially important for employees of the service sphere.

In the V.I. Dahl's "Interpreting Dictionary", the term hospitality means "hospitality in reception and participation of guests, a free acceptance and treat of travelers or strangers". It should be noted that hospitality is not only one of the fundamental concepts of human civilization, but also the industry that is rapidly developing and provides jobs to millions of people. The psychology of hospitality is to be able to offer a warm acceptance for guests, to create a calm and benevolent atmosphere. The psychology of hospitality manifests itself, first of all, in terms of guest, that is, in the understanding of the desires or problems of guest, especially those that he did not count. If the guest will notice that the staff of the hotel envisaged his desires, they took into account his fears, and then he will feel respect for himself, which in turn will give gratitude and pleasure.

Employees of hotels must understand that the client comes to visit not personally to the maid, the administrator, the waiter; he does not need their personal attitude. The a priori assumes that the hotel staff should with respect to the client's needs; all guests are waiting for a respectful attitude towards themselves and are ready tolerated to treat household problems, if they meet respect, benevolence and attention from the service personnel. All this indicates that in the psychology of hospitality, a special role is played by social needs. The technology of hospitality is manifested in the way to protect the client from the internal, sometimes an unattractive, manufacturing side of the hotel life. The client must get everything necessary in order to feel respect for itself from the personnel, to receive services at the most advantageous "gift" submission, but client not to be a witness to the preparation and service process (room cleaning, changes in linen, etc.), to see the internal life of the hotel, to know the details of the biography of employees, their relationships. Minor misses admitted at least one hotel staff can be the cause of dissatisfaction with the guest as a whole.

\section{CONCLUSIONS}

Hospitality is the art of trifles, therefore, the work of each employee in the hotel is equally important and from the behavior of each of them directly depends on how the recreation of the guest. Of great importance in customer service has a respectful attitude of staff to any cultural traditions of their guests. The acquisition of any hotel is professional and educated staff, which can communicate with customers in several languages, and a pleasant experience of enlightenment, level of professional knowledge, tactfulness and flexibility in communication. However, with all the importance 
of a professional organization of communication, capable of reducing communicative risks, professionals in the field of tourism and hospitality are acutely lacking. In many respects, this is determined by a relatively low level of services provided, low quality of service. In hotels, even in managerial positions are forced to put up with workers without proper qualification.

At the same time, tourism, tourism reality is not possible without professionalslogistics capable of developing a complex route; make it as convenient as possible. After all, it is not a secret that the attractiveness of Europe as a vacation site is not in the last turn related to the transport availability, the provision of flights and terminals, the branching of railway highways and highways, the presence of a huge number of transport enterprises, ready to take over the part of the care of the route. The short period of the tourism season does not allow the infrastructure, and the lack of infrastructure and the necessary set of specialists do not allow implementing the projects to extend the season. Even in the variant, when such a project is being developed at the state level, the lack of qualified specialists becomes an extremely serious problem. It would seem that today in universities and colleges of the country there is mass training of managerial manager and linear personnel for tourism. However, the saturation of the labor market is required by the number of highly skilled specialists. The tourism market, as well as tourist reality, is developing extremely rapidly. Those directions, which were still elite yesterday, are actively used in a mass tourism today; there are new directions, new tourist centers and technologies.

\section{REFERENCES}

Baum, T. (2002) Skills and training for the hospitality sector: a review of issues, Journal of Vocational Education and Training, 54:3, 343-364, DOI:10.1080/13636820200200204

Chhabra, D., Healy, R., \& Sills, E. (2003). Staged authenticity and heritage tourism. Annals of Tourism Research, 30(3), 702-719.

Coen, E. (1984) The Sociology of Tourism: Approaches, Issues, and Findings. Annual Review of Sociology. Vol. 10, 373-392.

Globalization and the Third World. A Study of Negative Consequences. (2006). London: Palgrave Macmillan. 269. Gusfield, J. (1984). Secular Symbolism: Studies of Ritual, Ceremony, and the Symbolic Order in Modern Life. Annual Review of Sociology. Vol. 10, 417-435.

Hospitality industry and the service culture in Europe (2019). Retrieved from: https://www.researchgate.net/ publication/323191362_Hospitality_industry_and the service_culture_in_Europe.

Koc, E. (2020). Cross-Cultural Aspects of Tourism and $\bar{H}$ ospitality. A Services Marketing and Management Perspective. London: Routledge. 370 p.

Kuslovan, S. (2003). Managing Employee Attitudes and Behaviors in the Tourism and Hospitality Industry. New York: Nova Science.

Michaelides, R. (2017). Hospitality industry and the service culturein Europe. Tourism and Travelling (open-access), 1(1), 15-19.

Moufakkir O. (2013). Culture shock, what culture shock? Tourist Studies. Vol. 11, 322-340. https://doi. org/10.1177/1468797613498166

Oberg, K. (1960). Culture Shock: Adjustment to New Cultural Environment, Practical Anthropology, 7, $177-$ 182.

Otto, J. E., \& Ritchie, J. B. (1996). The service experience in tourism. Tourism Management, 17(3), $165-174$. https://doi.org/10.1016/0261-5177(96)00003-9

Tourism and Culture Synergies (2018). UNWTO. Madrid. https://doi.org/10.18111/9789284418978.

Westcott M., Anderson, W. (2020). Introduction to Tourism and Hospitality in BC - 2nd Edition. Retrieved from: https://opentextbc.ca/introtourism/ 


\section{СПИСОК ВИКОРИСТАНОЇ ЛІТЕРАТУРИ}

Baum, T. Skills and training for the hospitality sector: a review of issues. Journal of Vocational Education and Training. 2002. 54:3, 343-364. DOI:10.1080/13636820200200204

Chhabra D., Healy R., Sills E. Staged authenticity and heritage tourism. Annals of Tourism Research. 2003, 30(3), 702-719. DOI: 10.1016/S0160-7383(03)00044-6

Coen E. The Sociology of Tourism: Approaches, Issues, and Findings. Annual Review of Sociology. 1984, Vol. 10, 373-392.

Globalization and the Third World. A Study of Negative Consequences. London: Palgrave Macmillan. 2006. $269 \mathrm{p}$

Gusfield J. Secular Symbolism: Studies of Ritual, Ceremony, and the Symbolic Order in Modern Life. Annual Review of Sociology. 1984. Vol. 10, 17-435.

Hospitality industry and the service culture in Europe. 2019. Available from: https://www.researchgate.net/publication/323191362 Hospitality industry and the service culture in Europe (дата звернення 02 травня 2021)

Koc E. Cross-Cultural Aspects of Tourism and Hospitality. A Services Marketing and Management Perspective. London: Routledge. 2020. 370 p.

Kuslovan, S. Managing Employee Attitudes and Behaviors in the Tourism and Hospitality Industry. New York: Nova Science. 2003.

Michaelides R.. Hospitality industry and the service culturein Europe. Tourism and Travelling (open-access). 2020. 1(1), 15-19. DOI: https://doi.org/10.21511/tt.1(1).2017.02

Moufakkir O. Culture shock, what culture shock? Tourist Studies. 2013. Vol. 11. pp. 322-340. DOI: https://doi. org/10.1177/1468797613498166

Oberg, K. Culture Shock: Adjustment to New Cultural Environment. Practical Anthropology. 1960. Vol. 7. $177-182$.

Otto J.E., Ritchie J.B. The service experience in tourism. Tourism Management, 1996, 17(3), 165-174. DOI: https://doi.org/10.1016/0261-5177(96)00003-9

Tourism and Culture Synergies, UNWTO, Madrid, 2018. DOI: https://doi.org/10.18111/9789284418978.

Westcott M., Anderson W. Introduction to Tourism and Hospitality in BC - 2nd Edition. 2020. https://opentextbc.ca/introtourism

Надійшла 20.05.2021

Л. В. Транченко ${ }^{1}$, доктор економ. наук, професор

В. В. Яворська ${ }^{2}$, доктор геогр. наук, професор

В. А. Сич², канд. геогр. наук, доцент

С. В. Тимчук ${ }^{1}$, канд. економ. наук, доцент

Н. В. Терещук ${ }^{1}$, канд. економ. наук, ст. викладач

'Уманський національний університет садівництва,

кафедра туризму та готельно-ресторанної справи,

вул. Інститутська, 1, м. Умань, Черкаська обл., 20305, Україна

lydatranch@gmail.com

${ }^{2}$ Одеський національний університет імені I. I. Мечникова,

кафедра економічної та соціальної географії і туризму,

вул. Дворянська 2, м. Одеса, 65082, Україна

yavorskaya@onu.edu.ua

\section{ОСОБЛИВОСТІ КОМУНІКАЦІЇ В ІНДУСТРІЇ ГОСТИННОСТІ В КОНТЕКСТІ ГЛОБАЛІЗАЦЇ̈}

Резюме

У статті розглянуто комунікаційні особливості, що виникають у туристичній сфері при відвідуванні туристами відмінних за етнічними, мовними, культурними особливостями країн. Початок XXI ст. характеризується домінуванням 
глобалізаційних тенденцій у процесі розвитку міжнародних відносин. Світовий ринок товарів і послуг перетворюється у єдиний глобальний економічний простір, у якому розвиток окремого сегмента стає закономірним наслідком ефективності процесів інтернаціоналізації, транснаціоналізації та міжнародної комунікації. Мета статті - з'ясувати комунікаційні особливості в сфері туризму в умовах глобалізації сучасного суспільства. В дослідженні зазначені шляхи подолання або пом'якшення туристом культурного шоку. Визначено, що безпечною формою занурення у чуже середовище $\epsilon$ культура обслуговування, а європейські стандарти виступають простором-посередником між туристом i чужою культурою. Стандартизована культура обслуговування і прийнятий в суспільстві діловий етикет здатні компенсувати культурний шок, для цього в країні має скластися професійна культура співробітника сфери гостинності.

Ключові слова: туризм, індустрія туризму, міжкультурні комунікації, соціальне середовище туризму, гостинність.

Л. В. Транченко ${ }^{1}$, доктор эконом. наук, профессор

В.В. Яворская ${ }^{2}$, доктор геогр. наук, профессор

В.А. Сыч², канд. геогр. наук, доцент

С. В. Тымчук ${ }^{1}$, канд. эконом. наук, доцент

Н. В. Терещук ${ }^{1}$, канд. эконом. наук, ст. преподаватель

${ }^{1}$ Уманьский национальный университет садоводства,

кафедра туризма и отельно-ресторанного дела,

ул. Институтская, 1, г. Умань, Черкасская обл., 20305, Украина

lydatranch@gmail.com

${ }^{2}$ Одесский национальный университет имени И. И. Мечникова, кафедра экономической и социальной географии и туризма, ул. Дворянская 2, г. Одесса, 65082, Украина

yavorskaya@onu.edu.ua

\section{ОСОБЕННОСТИ КОММУНИКАЦИИ В ИНДУСТРИИ ГОСТЕПРИИМСТВА В КОНТЕКСТЕ ГЛОБАЛИЗАЦИИ}

\footnotetext{
Резюме

В статье рассмотрены коммуникационные особенности, возникающие при посещении туристами различных стран, отличных по своим языковым и культурным особенностям. Начало XXI века характеризуется доминированием глобализационных тенденций в процессе развития международных отношений. Мировой рынок товаров и услуг превращается в единое глобальное экономическое пространство, в котором развитие отдельного сегмента становится закономерным следствием эффективности процессов интернационализации, транснационализации и международной коммуникации. Цель статьи - выяснить коммуникационные особенности в сфере туризма в условиях глобализации современного общества. В исследовании указанные пути преодоления или
} 
смягчения туристом культурного шока. Определено, что безопасной формой погружения в чужую среду является культура обслуживания, а европейские стандарты выступают пространством-посредником между туристом и чужой культурой. Стандартизированная культура обслуживания и принятый в обществе деловой этикет способны компенсировать культурный шок, для этого в стране должна сложиться профессиональная культура сотрудников сферы гостеприимства.

Ключевые слова: туризм, индустрия туризма, межкультурные коммуникации, социальная среда туризма, гостеприимство. 